\title{
DETERMINING OF HEAVY METALS CONTENT IN THREE LEAFY VEGETABLES TREATED WITH COMPOST PRODUCED BY QUASHIE MUNICIPAL SOLID WASTE PLANT
}

\author{
ABdi IBRAHIm ABDI ${ }^{*}$ and SONJA SCHLOSSER ${ }^{* *}$ \\ * Dept. of Plant Protection, College of Agriculture, University of Duhok, Kurdistan Region-Iraq \\ Laboratory Manager of Inorganic Analysis, Analytical Chemistry, University of Hohenheim, Stuttgart-Germany
}

(Received: November 5, 2018; Accepted for Publication: December 10, 2018)

\begin{abstract}
1.ABSTRACT
Due to prior analysis of compost produced at the Quashie waste facility, which disclosed increased levels in heavy metals (specifically lead, cadmium, copper, nickel, chromium, cobalt and zinc); this study tested vegetables grown using the same compost for these same metals in three leafy vegetables (Arugula, Celery and Chard). The results showed various responses of the plants to the treatments in terms of all studied variables. For most variables, plant applied with animal manure were superior to those that treated with compost; yet, they were not significantly different from those that applied by six and nine litters of compost. The heavy metals content of all samples was in accordance to the European Food Law, except for chromium, which showed to be toxic in one celery sample $\left(0,53 \mathrm{mg} \cdot \mathrm{kg}^{-1}\right)$, , and cannot be used for human consumption. Concentrations of heavy metals in control plants were close to those of treated plants with compost showing a possible contamination from different source. This test ensures appropriate use of the compost and prevents the use of potentially harmful compost in the future.
\end{abstract}

KEYWORDS: Compost, Heavy metals, Leafy vegetables, Animal manure.

\section{INTRODUCTION}

$\mathbf{T}$ The solid waste is increasing with the population growth; therefore, a proper management of this type of waste has become crucial (Çalışkan, Barış̧̧ı et al. 2014). Quashie waste facility is the largest facility for waste management in Duhok governorate, Kurdistan of Iraq and in whole Iraq. The facility was built in a good standard; one of the products that separated from the waste is the organic matters that is converted to compost, and then can be reused for plants.

In order to provide good quality compost, the facility is assessing the product periodically. The assessments are conducted by the facility, governmental institutions, University of Duhok and Deutsche Gesellschaft für Internationale Zusammenarbeit (GIZ). Because the organic waste is not separated from the other waste, the facility, with GIZ cooperation, has decided to analyze a number of samples for heavy metals content according to European standards (Table 1).
Both samples were collected in December 2013 and in March 2017 showed concentrations above the limit according the German Bio-WasteRegulation. It is understandable that the values of the samples from "fresh compost" are higher than the values of the samples from "old compost", because the old compost has less organic matter and therefore the heavy metals are distributed in less dry matter. At the end, the amounts of heavy metals distributed on the soil by fresh or old compost are about the same, because of the same materials, used for composting. This is because heavy metals will not evaporate or degrade during the compost process under normal temperature conditions (Christian Letalik, personal communications, 2017).

Table (1) shows increased levels of heavy metals in the compost specifically lead, cadmium, copper and zinc. However, previous studies on heavy metals behavior in different soils showed limited movement of heavy metals in alkaline and clay soils (McLean, Bledsoe et al. 1992). Therefore, it is important to know whether the 
concentration of heavy metals inside plant tissues is accordance to the European standards or not.

Studies showed significant differences in corn production when applied by animal manure compared to those that applied by compost (Eghball, Ginting et al. 2004). On the other hand, a study about heavy metals accumulation in Radish plant showed that the heavy metals, particularly $\mathrm{Zn}$, are accumulating in leaves more than other parts of the plant (Abdel and Ibrahim 2018). Thus, it is important to study the variation in leafy plants production using both animal manure and compost. This will help the decision makers to choose the right fertilizers according to the results, after comparing the price and other factors of each of them.

This study examines the concentrations of heavy metals in three leafy vegetables (arugula, celery and chard). Particularly, it tests the hypotheses that: (i) The concentration of the six heavy metals in three leafy vegetables is low and variable; (ii) There is no contamination from air pollution; and (iii) The Plants will respond to animal manure more than the compost in terms of growth and the studied variables.

Table (1): Heavy metal concentrations of compost samples from Quashie (March 2017 and December 2013).

\begin{tabular}{|c|c|c|c|c|c|c|}
\hline & & Heavy $n$ & s in compos & Quashie comp & st, limits for & ope \\
\hline \multirow[t]{3}{*}{ Heavy metals } & $\begin{array}{c}\text { Fresh compost } \\
\text { (not completely } \\
\text { decomposed), } \\
\text { March } 17\end{array}$ & $\begin{array}{c}\text { Old compost } \\
\text { (completely } \\
\text { decomposed), } \\
\text { March } 17\end{array}$ & Limits & December 13 & Limits & Limits \\
\hline & Quashie & Quashie & BKG BRD* $^{*}$ & Quashie & Italian & Spain \\
\hline & mg.kg ${ }^{-1} \mathrm{dm}$ & $\mathrm{mg} \cdot \mathrm{kg}^{-1} \mathrm{dm}$ & mg. $\mathrm{kg}^{-1} \mathrm{dm}$ & $\mathrm{mg} \cdot \mathrm{kg}^{-1} \mathrm{dm}$ & $\mathrm{mg} \cdot \mathrm{kg}^{-1} \mathrm{dm}$ & $\mathrm{mg} \cdot \mathrm{kg}^{-1} \mathrm{dm}$ \\
\hline Thallium $\mathrm{TI}$ & $<0.1$ & $<0.1$ & - & - & - & - \\
\hline Arsenic & 1.4 & 2.1 & - & - & - & - \\
\hline Lead & 129 & $214^{* *}$ & 150 & 99.6 & 140 & 1.200 \\
\hline Cadmium Cd & $3.77^{* *}$ & $6.64^{* *}$ & 1.5 & $2.31^{* *}$ & 1.5 & 40 \\
\hline Chromium Cr & 30.5 & 37.2 & 100 & 25.5 & 100 & 750 \\
\hline Nickel Ni & 34.8 & 42.8 & 50 & 36.1 & 50 & 400 \\
\hline Mercury $\mathrm{Hg}$ & 0.51 & 0.68 & 1 & 0.3 & 1.5 & 25 \\
\hline Copper & $221^{* *}$ & $298^{* *}$ & 100 & $126^{* *}$ & 300 & 1.750 \\
\hline Zinc & $505^{\star \star}$ & $680^{* *}$ & 400 & 340 & 500 & 4.000 \\
\hline
\end{tabular}

* Federal Compost Law Germany, ** above limits, dm dry matter.

\section{METHODOLOGY}

This study was conducted in the field at the University of Duhok (UOD), Kurdistan regionIraq. The experimental units were distributed randomly using RCBD design. Three concentrations of compost $\left(3 \quad 1 .\left(\mathrm{m}^{2}\right)^{-1}(\mathrm{C} 3), 6\right.$ 1. $\left(\mathrm{m}^{2}\right)^{-1}$ (C6) and 9 1. $\left.\left(\mathrm{m}^{2}\right)^{-1}(\mathrm{C} 9)\right)$; and animal manure (AM) (six litters. $\left.\left(\mathrm{m}^{2}\right)^{-1}\right)$ were compared to control using ANOVA and Duncan's multiple test. While the recommended amount of compost is between 4 and 10 liters per $\mathrm{m}^{2}$ in Germany (Christian Letalik, personal communications, 2017), Iraqi soil does not require quite as much compost, which brought us to decide to use the compost concentrations of 3,6 , and 9 liters per $\mathrm{m}^{2}$ respectively, providing scientifically valid, equal additions of soil in each treatment. The plots $(0.5$ $\mathrm{m}^{2}$ ) were distributed randomly within each block.
A study about heavy metals accumulation in Radish plant showed that the heavy metals, particularly $\mathrm{Zn}$, are accumulating in leaves more than other parts of the plant (Abdel and Ibrahim 2018). Therefore, three leafy vegetables (Chard, Arugula and Celery) were planted with three replications for each of them. The seeds were sown on 14/9/2017 at a rate of Celery $4.2 \mathrm{gm}^{-1}$, arugula $4.2 \mathrm{gm}^{-1}$ and chard $4.4 \mathrm{gm}^{-1}$ then the extra plants were thinned (pulled out) to have more space. Drip irrigation system was used for water supply. To accelerate the germination, the plots were covered by a sheet of polyethylene. A number of morphological traits were measured between 23 to 26 of October 2017. Those morphological traits included, plant height $(\mathrm{cm})$, leaf width $(\mathrm{cm})$, leaf length $(\mathrm{cm})$, petiole thickness $(\mathrm{mm})$, fresh weight and dry weight $(\mathrm{g})$. In addition, leaf area $\left(\mathrm{cm}^{2}\right)$ was measured using a 
smartphone application (petiole, Version 0.7 by Petiole LTD, http://petioleapp.com, 2017). Six leaves within each plot were selected randomly, and their means were calculated to represent the leaf area. The samples were oven dried according to (Brower, Zar et al. 1998; Godbold and Hüttermann 1988; and Teramura, Perry et al. 1984), and the concentration of heavy metals was measured at Hohenheim University, Germany. In Germany, the samples were digested according to (VDLUFA, 2011a) by microwave heated digestion with the MLS Ultraclave III and then measured by the Perkin Elmer ICP-MS NexION 300X (VDLUFA, 2011b). Approximately 0.2 to $0.3 \mathrm{~g}$ of each sample was measured for digestion process. One $\mathrm{mL}$ of $\mathrm{H}_{2} \mathrm{O}$ and then $2.5 \mathrm{~mL}$ of $\mathrm{HNO}_{3}$ were applied to the samples. After digestion, $\mathrm{H}_{2} \mathrm{O}$ was added to the solutions until they became $10 \mathrm{~mL}$. The mean of the three replications were extracted to represent the value of certain heavy metal content.

\section{RESULTS AND DISCUSSION 4.1. Morphological Traits}

The results showed various responses of the plants to the treatments in terms of all studied variables (Tables 2, 3, 4 and 5). Arugula plant with AM, C3, C6 and C9 were significantly higher than control plants. On the other hand, celery plants were significantly longer when they treated with $\mathrm{AM}$ and $\mathrm{C} 3$; however, celery plants treated with C6 and C9 were not significantly longer than those of control. Contrarily, chard plants were significantly longer in AM, C6 and C9 treatments than those plants in $\mathrm{C} 3$ and control treatments. Yet, overall, AM produced superior plants in terms of plant height, although plants treated with all concentration of compost gave significantly higher plants than those in control (Table 2).

Wider leaves were produced when plants were treated with AM, C3, C6 and C9 (Table 2). Although arugula and chard plants produced wider leaves when they applied by AM, their leaves were not significantly wider than those plants applied with all concentrations of compost. Whereas the results showed no significant differences in leaf width of celery plants within all plots (Table 2).

Table (2): The effect of AM and three concentrations of compost compared to control on plant height and leaf width of arugula, celery and chard.

\begin{tabular}{|c|c|c|c|c|c|c|c|c|}
\hline \multicolumn{5}{|c|}{ Plant height $(\mathrm{cm})$} & \multicolumn{4}{|c|}{ Leaf Width (cm) } \\
\hline \multirow[t]{2}{*}{ Treatments } & \multicolumn{3}{|c|}{ Plants } & \multirow[b]{2}{*}{$\begin{array}{l}\text { Mean of } \\
\text { Treatments }\end{array}$} & \multicolumn{3}{|c|}{ Plants } & \multirow[b]{2}{*}{$\begin{array}{l}\text { Mean of } \\
\text { Treatments }\end{array}$} \\
\hline & Arugula & Celery & Chard & & Arugula & Celery & Chard & \\
\hline AM & $35.67 \mathrm{bc}$ & $20.35 \mathrm{e}$ & $46.53 \mathrm{a}$ & $34.18 \mathrm{a}$ & $9.83 \mathrm{c}$ & $3.84 \mathrm{e}$ & $14.67 \mathrm{a}$ & $9.45 \mathrm{a}$ \\
\hline C3 & $34.07 \mathrm{bc}$ & 19.17 e & $36.48 \mathrm{bc}$ & $29.9 \mathrm{~b}$ & $8.03 \mathrm{~cd}$ & $3.51 \mathrm{e}$ & $14.22 \mathrm{ab}$ & $8.59 \mathrm{a}$ \\
\hline C6 & $34.2 \mathrm{bc}$ & $15.32 f$ & $43.58 \mathrm{a}$ & $31.03 \mathrm{~b}$ & $8.63 \mathrm{~cd}$ & $2.99 \mathrm{e}$ & $14.39 \mathrm{ab}$ & $8.67 \mathrm{a}$ \\
\hline C9 & $33.03 \mathrm{c}$ & $14.14 \mathrm{f}$ & $43.83 \mathrm{a}$ & $30.33 \mathrm{~b}$ & $8.77 \mathrm{~cd}$ & $3.11 \mathrm{e}$ & $14.4 \mathrm{ab}$ & $8.76 \mathrm{a}$ \\
\hline Control & $28.97 d$ & $13.31 \mathrm{f}$ & $37.44 \mathrm{~b}$ & $26.57 \mathrm{c}$ & $6.9 \mathrm{~d}$ & $2.48 \mathrm{e}$ & $12.35 \mathrm{~b}$ & $7.24 b$ \\
\hline
\end{tabular}

Different letters within each comparison represent significant differences according to Duncan's multiple range test at $5 \%$ level.

Longer leaves and thicker petioles were found when plants were treated with AM, C6 and C9 (Table 3). Arugula and chard gave longer leaves and thicker petiole when AM, C6 and C9 were applied, except for chard leaf length when applied by $\mathrm{C} 9$. Interestingly, the length of leaves and the petioles thickness of celery plants found to be significantly the same in all treatments (Table 3). 
Journal of University of Duhok., Vol. rr, No.1 (Agri. and Vet. Sciences), Pp 122-131, r. 19

Table (3): The effect of AM and three concentrations of compost compared to control on leaf length and petiole thickness of arugula, celery and chard.

\begin{tabular}{|c|c|c|c|c|c|c|c|c|}
\hline \multicolumn{5}{|c|}{ Leaf length $(\mathrm{cm})$} & \multicolumn{4}{|c|}{ Petiole Thickness (mm) } \\
\hline \multirow[t]{2}{*}{ Treatments } & \multicolumn{3}{|c|}{ Plants } & \multicolumn{5}{|c|}{ Plants } \\
\hline & Arugula & Celery & Chard & $\begin{array}{l}\text { Mean of } \\
\text { Treatments }\end{array}$ & Arugula & Celery & Chard & $\begin{array}{l}\text { Mean of } \\
\text { Treatments }\end{array}$ \\
\hline AM & $19.47 \mathrm{~cd}$ & $3.06 \mathrm{~g}$ & $30.26 \mathrm{a}$ & $17.59 \mathrm{a}$ & $5.657 \mathrm{~d}$ & $1.847 \mathrm{~g}$ & $12.727 \mathrm{a}$ & $6.743 \mathrm{a}$ \\
\hline C3 & 15.63 ef & $3.05 \mathrm{~g}$ & $22.2 \mathrm{c}$ & $13.63 \mathrm{~b}$ & $4.677 \mathrm{e}$ & $1.377 \mathrm{~g}$ & $9.55 \mathrm{~b}$ & $5.201 \mathrm{~b}$ \\
\hline C6 & $18.17 \mathrm{de}$ & $2.54 \mathrm{~g}$ & $27.27 \mathrm{ab}$ & $15.99 \mathrm{a}$ & $5.143 \mathrm{de}$ & $1.347 \mathrm{~g}$ & $12.487 \mathrm{a}$ & $6.326 \mathrm{a}$ \\
\hline c9 & $18.07 \mathrm{de}$ & $2.58 \mathrm{~g}$ & $26.69 \mathrm{~b}$ & $15.78 \mathrm{a}$ & $5.41 \mathrm{de}$ & $1.29 \mathrm{~g}$ & $12.177 \mathrm{a}$ & $6.292 \mathrm{a}$ \\
\hline Control & $13.2 \mathrm{f}$ & $4.58 \mathrm{~g}$ & $21.85 \mathrm{c}$ & $13.21 \mathrm{~b}$ & $3.317 f$ & $0.937 \mathrm{~g}$ & $7.947 \mathrm{c}$ & $4.067 \mathrm{c}$ \\
\hline
\end{tabular}

Different letters within each comparison represent significant differences according to Duncan's multiple range test at $5 \%$ level.

The statistical findings showed significant differences in fresh weight, but not dry weight, of all plants together as compared to those found in control (Table 4). Regarding single plant type, arugula and celery plants showed no significant differences in fresh and dry weight among treatments. However, the fresh weight of chard was superior when the plants applied by AM and C6. Whereas dry weight of chard plants was superior when plants applied by C6 (Table 4). The leaves of chard are larger than other studied plants; this could affect the results of overall plants together.

Table (4): The effect of AM and three concentrations of compost compared to control on fresh weight and dry weight of arugula, celery and chard.

\begin{tabular}{|c|c|c|c|c|c|c|c|c|}
\hline \multicolumn{5}{|c|}{ Fresh Weight (g) } & \multicolumn{4}{|c|}{ Dry Weight (g) } \\
\hline \multirow[t]{2}{*}{ Treatments } & \multicolumn{3}{|c|}{ Plants } & \multicolumn{5}{|c|}{ Plants } \\
\hline & Arugula & Celery & Chard & $\begin{array}{l}\text { Mean of } \\
\text { Treatments }\end{array}$ & Arugula & Celery & Chard & $\begin{array}{l}\text { Mean of } \\
\text { Treatment } \\
\mathrm{s}\end{array}$ \\
\hline AM & $32.93 \mathrm{c}$ & $1.74 \mathrm{~d}$ & $88.58 \mathrm{a}$ & $41.08 \mathrm{a}$ & $2.6 \mathrm{~d}$ & $0.29 \mathrm{f}$ & $9.36 \mathrm{ab}$ & $4.083 \mathrm{a}$ \\
\hline C3 & $28.32 \mathrm{c}$ & $1.17 \mathrm{~d}$ & $67.57 \mathrm{~b}$ & $32.35 \mathrm{ab}$ & $2.83 \mathrm{~d}$ & $0.213 \mathrm{f}$ & $6.92 \mathrm{c}$ & $3.321 \mathrm{a}$ \\
\hline C6 & $30.71 \mathrm{c}$ & $0.95 d$ & $96.04 \mathrm{a}$ & 42.57 a & $2.85 \mathrm{~d}$ & $0.177 \mathrm{f}$ & $10.303 \mathrm{a}$ & $4.443 a$ \\
\hline C9 & $26.99 c$ & $0.78 d$ & $86.54 \mathrm{a}$ & $38.1 a b$ & $3.1 \mathrm{~d}$ & 0.14 ef & $8.563 a b c$ & $3.934 \mathrm{a}$ \\
\hline Control & $21.31 \mathrm{c}$ & $0.78 d$ & $65.59 \mathrm{~b}$ & $29.23 \mathrm{~b}$ & $2.223 \mathrm{de}$ & 0.163 ef & $7.437 \mathrm{bc}$ & $3.274 a$ \\
\hline
\end{tabular}

Different letters within each comparison represent significant differences according to Duncan's multiple range test at $5 \%$ level.

Interestingly, the leaf area of arugula and celery found to be significantly the same in all treatments; however, leaf area of chard was significantly larger when the plants applied by AM, C6 and C9 (Table 5). This, again, could be the reason behind the significant differences among treatments when all plants measured together.

Celery germinated later than other two tested plants. In addition, continues irrigation caused washing off for the nutrients far from their shallow roots. Those two reasons could be the key of not showing response to AM and compost. 
Table (5): The effect of AM and three concentrations of compost compared to control on leaf area $\left(\mathrm{cm}^{2}\right)$ of arugula, celery and chard.

\begin{tabular}{lllll}
\hline \multirow{2}{*}{ Treatments } & \multicolumn{4}{c}{ Plants } \\
\cline { 2 - 5 } & Arugula & Celery & Chard & Mean of Treatments \\
\hline AM & $124.1 \mathrm{c}$ & $20.3 \mathrm{~d}$ & $333.7 \mathrm{a}$ & $\mathbf{1 5 9 . 4 ~ a}$ \\
\hline C3 & $109.3 \mathrm{c}$ & $12.3 \mathrm{~d}$ & $237 \mathrm{~b}$ & $\mathbf{1 1 9 . 5} \mathbf{b c}$ \\
\hline $\mathbf{C 6}$ & $111.8 \mathrm{c}$ & $9.4 \mathrm{~d}$ & $320.4 \mathrm{a}$ & $\mathbf{1 4 7 . 2} \mathbf{a b}$ \\
\hline $\mathbf{C 9}$ & $117.3 \mathrm{c}$ & $8.8 \mathrm{~d}$ & $318.7 \mathrm{a}$ & $\mathbf{1 4 8 . 3} \mathbf{a b}$ \\
\hline Control & $85.7 \mathrm{c}$ & $8 \mathrm{~d}$ & $189.6 \mathrm{~b}$ & $\mathbf{9 4 . 5} \mathbf{c}$ \\
\hline
\end{tabular}

Different letters within each comparison represent significant differences according to Duncan's multiple range test at $5 \%$ level.

\subsection{The Concentration Of Heavy Metals}

The results supported the first hypothesis that the concentration of the six heavy metals in three leafy vegetables is low and variable, except chromium, which was quit high in one celery sample. Although there are some differences between the triple determinations for some elements, the results calculated on the fresh material before drying are more similar because they are smaller. It is enough for the evaluation of the samples. Comparing the results to European food law and other literature will be discussed in details. The concentrations of the six heavy metals in both dry and fresh weights for arugula, celery and chard are shown in Table (6).

\subsubsection{Copper Cadmium and Lead}

For copper $(\mathrm{Cu})$, compared to this limits, calculated on the fresh material, given in the COMMISSION (2008) and No (2005): arugula: $100 \mathrm{mg} \cdot \mathrm{kg}^{-1}$; chard: $20 \mathrm{mg} \cdot \mathrm{kg}^{-1}$; celery leaves: $50 \mathrm{mg} \cdot \mathrm{kg}^{-1}$; celery: $20 \mathrm{mg} \cdot \mathrm{kg}^{-1}$, the samples are in accordance with the European food law. For Cadmium (Cd) compared to the limits calculated on the fresh material given in the REGULATION (2014) and VO (EG) (1881/2006), leafy vegetables, celery leaves and celery: $0,20 \mathrm{mg} \cdot \mathrm{kg}^{-1}$; the samples are also in accordance with the European food law. Same thing was shown in the results for lead $(\mathrm{Pb})$ (COMMISSION 2015; and COMMISSION (2006): Leafy vegetables: $0,30 \mathrm{mg} \cdot \mathrm{kg}^{-1}$.

\subsubsection{Nickle (Ni):}

According to the European Food Safety Authority (EFSA), the Tolerable Daily Intake
(TDI) for nickel is $2,8 \mathrm{mg} \cdot \mathrm{kg}^{-1}$ body weight. If we have a person of $60 \mathrm{~kg}$ Body weight; therefore, the tolerable daily intake would be $168 \mu \mathrm{g}$. The sample with the highest amount of $\mathrm{Ni}$ was one replication of the $\mathrm{C} 3$ celery $\left(0,782 \mathrm{mg} \cdot \mathrm{kg}^{-1}\right)$. This mean that the Person can have about $215 \mathrm{~g}$ of this celery sample to be in accordance of the TDI of Ni.

\subsubsection{Zinc ( $\mathrm{Zn})$ :}

According to the literature (Frede, W. ed., 2006), the Provisional Maximum Tolerable Daily Intake (PMTDI) for zinc is $1 \mathrm{mg} \cdot \mathrm{kg}^{-1}$ body weight. A sixty $\mathrm{kg}$ Person could have a daily intake of $60 \mathrm{mg} \mathrm{Zn}$. The sample with the highest amount of $\mathrm{Zn}$ was the third replication of C 3 celery $\left(5,04 \mathrm{mg} \cdot \mathrm{kg}^{-1}\right)$. This means that a person can have about $11,9 \mathrm{~kg}$ of this celery sample in his meal to be in accordance of the PMTDI of Zn.

\subsubsection{Chromium $(\mathrm{Cr})$ :}

Only the total amount of $\mathrm{Cr}$ has been analyzed in this study. The amount of $\mathrm{Cr}$ in other foods is much higher, e.g. quince: 17 mg. $\mathrm{kg}^{-1}$, Rice: $6,8 \mathrm{mg} \cdot \mathrm{kg}^{-1}$, brazil nuts: 1 $\mathrm{mg} \cdot \mathrm{kg}^{-1}$. The sample with the highest amount of $\mathrm{Cr}$ was the third replication of $\mathrm{C} 3$ celery (0,53 mg. $\left.\mathrm{kg}^{-1}\right)$. Chromium (VI) compounds shown to be toxic and can not be used for human consumption.

\subsubsection{Cobalt (Co):}

According to Belitz, H.D., Grosch, W. and Schieberle, P. (2008), the daily intake of cobalt is between 5-200 $\mu \mathrm{g}$. Compared to other foods (e.g. chocolate: 0,312 mg. $\mathrm{kg}^{-1}$, cocoa powder: $1,013 \mathrm{mg} \cdot \mathrm{kg}^{-1}$ ), the amounts of Co in the samples are low. 
Journal of University of Duhok., Vol. rr, No.1 (Agri. and Vet. Sciences), Pp 122-131, r. 19

Table (6): The concentration of six heavy metals in both dry weight and fresh weight of arugula, celery and chard. The mean of three replications was subtracted for each treatment.

\begin{tabular}{|c|c|c|c|c|c|c|c|c|c|c|c|c|c|c|c|}
\hline \multirow[b]{2}{*}{$\begin{array}{l}\text { Sample } \\
\text { name }\end{array}$} & \multicolumn{7}{|c|}{ Results (dry matter) } & \multirow[b]{2}{*}{ TS \% } & \multicolumn{7}{|c|}{ Results (fresh samples) } \\
\hline & $\begin{array}{c}\text { Cd } \\
\text { ICP- } \\
\text { MS } \\
\mathrm{mg} / \mathrm{kg}\end{array}$ & $\begin{array}{c}\mathrm{Cr} \\
\mathrm{ICP}- \\
\mathrm{MS} \\
\mathrm{mg} / \mathrm{kg}\end{array}$ & $\begin{array}{c}\text { Co } \\
\text { ICP- } \\
\text { MS } \\
\mathrm{mg} / \mathbf{k g}\end{array}$ & $\begin{array}{c}\mathrm{Cu} \\
\mathrm{ICP}- \\
\mathrm{MS} \\
\mathrm{mg} / \mathrm{kg}\end{array}$ & $\begin{array}{c}\mathrm{Ni} \\
\mathrm{ICP}- \\
\mathrm{MS} \\
\mathrm{mg} / \mathrm{kg}\end{array}$ & $\begin{array}{c}\mathrm{Pb} \\
\mathrm{ICP}- \\
\mathrm{MS} \\
\mathrm{mg} / \mathbf{k g}\end{array}$ & $\begin{array}{c}\mathrm{Zn} \\
\mathrm{ICP}- \\
\mathrm{MS} \\
\mathrm{mg} / \mathrm{kg}\end{array}$ & & $\begin{array}{c}\text { Cd } \\
\text { ICP-MS } \\
\text { mg/kg }\end{array}$ & $\begin{array}{c}\mathrm{Cr} \\
\mathrm{ICP}- \\
\mathrm{MS} \\
\mathrm{mg} / \mathrm{kg}\end{array}$ & $\begin{array}{c}\text { Co } \\
\text { ICP- } \\
\text { MS } \\
\mathrm{mg} / \mathbf{k g}\end{array}$ & $\begin{array}{c}\mathrm{Cu} \\
\mathrm{ICP}- \\
\mathrm{MS} \\
\mathrm{mg} / \mathrm{kg}\end{array}$ & $\begin{array}{c}\mathrm{Ni} \\
\mathrm{ICP}- \\
\mathrm{MS} \\
\mathrm{mg} / \mathrm{kg}\end{array}$ & $\begin{array}{c}\mathrm{Pb} \\
\mathrm{ICP}- \\
\mathrm{MS} \\
\mathrm{mg} / \mathrm{kg}\end{array}$ & $\begin{array}{c}\mathrm{Zn} \\
\text { ICP- } \\
\text { MS } \\
\mathrm{mg} / \mathrm{kg}\end{array}$ \\
\hline C3 Arugula & 0.996 & 2.451 & 0.348 & 5.347 & 2.543 & 0.303 & 21.771 & 9.979 & 0.099 & 0.246 & 0.035 & 0.533 & 0.255 & 0.030 & 2.848 \\
\hline C3 Celery & 0.183 & 4.441 & 0.581 & 9.181 & 6.473 & 0.692 & 46.953 & 10.200 & 0.019 & 0.451 & 0.059 & 0.940 & 0.657 & 0.070 & 3.615 \\
\hline C3 Chard & 0.159 & 1.483 & 0.441 & 6.697 & 1.393 & 0.212 & 20.291 & 18.635 & 0.030 & 0.278 & 0.082 & 1.241 & 0.260 & 0.040 & 2.088 \\
\hline C6 Arugula & 1.015 & 1.830 & 0.247 & 5.106 & 1.962 & 0.228 & 21.267 & 9.253 & 0.094 & 0.168 & 0.023 & 0.474 & 0.181 & 0.021 & 2.782 \\
\hline C6 Celery & 0.122 & 3.441 & 0.459 & 7.994 & 5.211 & 0.569 & 35.125 & 10.761 & 0.013 & 0.370 & 0.049 & 0.860 & 0.560 & 0.061 & 2.705 \\
\hline C6 Chard & 0.206 & 1.746 & 0.553 & 7.879 & 1.795 & 0.230 & 22.352 & 18.598 & 0.038 & 0.327 & 0.103 & 1.460 & 0.337 & 0.043 & 2.300 \\
\hline C9 Arugula & 1.020 & 1.698 & 0.242 & 5.362 & 1.923 & 0.224 & 21.781 & 11.544 & 0.118 & 0.198 & 0.028 & 0.615 & 0.223 & 0.026 & 2.849 \\
\hline C9 Celery & 0.131 & 3.079 & 0.409 & 8.566 & 4.477 & 0.956 & 41.009 & 9.835 & 0.013 & 0.304 & 0.040 & 0.847 & 0.443 & 0.096 & 3.158 \\
\hline C9 Chard & 0.190 & 1.588 & 0.476 & 7.706 & 1.607 & 0.209 & 24.241 & 17.361 & 0.032 & 0.276 & 0.083 & 1.343 & 0.279 & 0.037 & 2.494 \\
\hline $\begin{array}{l}\text { Control } \\
\text { Arugula } \\
\end{array}$ & 1.222 & 2.008 & 0.265 & 5.476 & 2.180 & 0.238 & 22.207 & 10.448 & 0.128 & 0.209 & 0.028 & 0.574 & 0.227 & 0.025 & 2.905 \\
\hline $\begin{array}{l}\text { Control } \\
\text { Celery }\end{array}$ & 0.162 & 3.494 & 0.456 & 7.705 & 5.668 & 0.505 & 37.592 & 11.277 & 0.018 & 0.394 & 0.052 & 0.868 & 0.639 & 0.057 & 2.895 \\
\hline $\begin{array}{l}\text { Control } \\
\text { Chard }\end{array}$ & 0.173 & 1.787 & 0.515 & 7.292 & 1.751 & 0.220 & 21.427 & 20.884 & 0.036 & 0.376 & 0.108 & 1.524 & 0.367 & 0.046 & 2.205 \\
\hline
\end{tabular}


Heavy metals movement and adsorption in the soil is influenced by many factors such as clay contents, soil $\mathrm{pH}$ and others (McLean, Bledsoe et al. 1992). McLean, Bledsoe et al. (1992) found that $\mathrm{Cd}$ and $\mathrm{Pb}$ are less soluble in those soils with high $\mathrm{pH}$ and clay contents, like almost all soils in Duhok. This is because $\mathrm{Cd}$ and $\mathrm{Pb}$ can be changed into other compounds by binding with carbon, oxygen and phosphorus that are more stable (McLean, Bledsoe et al. 1992). In addition, McLean, Bledsoe et al. (1992) addressed that clay soils can trap $\mathrm{Zn}$ rapidly in there particles. Accordingly, this could be the reason of having low amounts of heavy metals in the analyzed samples.

Interestingly, the results did not supported the second hypothesis that there is no contamination of heavy metals from air pollution (Table 6). The untreated plant by compost showed very close ratio of heavy metals to those plants that were treated by compost with different concentration (Table 6). A number of studies showed that there is a risk of possible contamination by heavy metals to the areas near the highways (Ferguson and Kim, 1991; De Miquel et al., 1997; Naqerotte and Day, 1998; Sezgin, Ozcan et al. 2004). The study location was about $150 \mathrm{~m}$ away from the highway. In addition, the quality of fuel that is used by most of cars in Duhok is poor due to its lower price. This could be the reason of having such concentrations of heavy metals in control plants. Sezgin, Ozcan et al. (2004) found toxic heavy metals, particularly $\mathrm{Zn}$, above the limit even about $500 \mathrm{~m}$ away from highways.

It can be concluded that the quality of compost in terms of production is competing the animal manure. In addition, the concentrations of the six heavy metals that were tested in this study are in accordance to the European standards. Although the previous samples of compost showed high concentrations of heavy metals, it did not necessarily means that they can be accumulated in the plant tissues. Furthermore, the existence of heavy metals in control plants showed the possibility of contamination by heavy metals from different source other than the compost. Accordingly, further studies are required to examine the contamination of soil, and air and plants close to the highways. Thus the compost can be used for vegetable production, but a number of recommendations must be taken into account.

During the study period, several important points have been noticed that can be changed for better quality compost. Firstly, the solid waste is collected all together from the sources; therefore, it can be recommended to separate the waste bins according to the type of the waste. This will prevent the heavy metals to contaminate the organic waste. Secondly, from the observations, there was a high amount of broken glasses in the compost. It can be solved by both separating the waste bins from the source and adjusting the machines in the facility to prevent passing the glasses. Thirdly, the compost was not decomposed properly. In addition, there was a high amount of sunflower's seed peels. Those peels cannot be decomposed easily, and they contain large amount of salt. This can also increase the salt in the compost which will negatively affect plants. Therefore, it is recommended to wash the organic waste before composting process in order to minimize the salts content. Furthermore, more time should be given to the compost to complete the decomposition process.

Further studies are required to compare the long-term effects of both animal manure and compost on the soil properties, texture, soil $\mathrm{pH}$ and nutrient content. In addition, "Petiole", a phone application, which used to measure the leaf area, provided accurate measurements, and it is recommended for research purposes in the future (figure 1). 


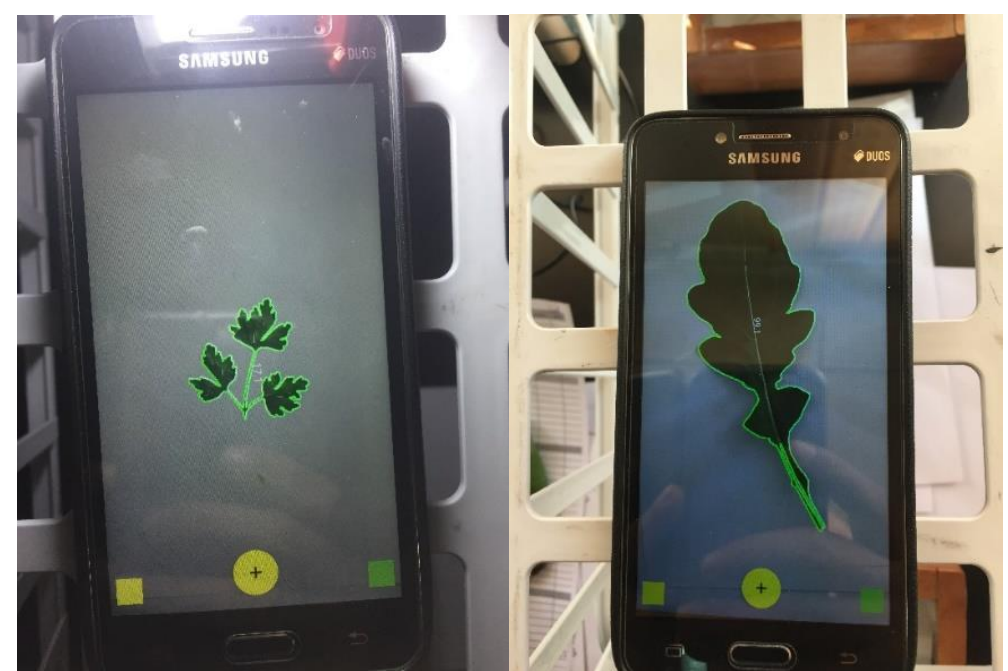

Fig. (1): The calculation of leaf area using Petiole phone application.

\section{ACKNOWLEDGMENT}

The field study was supported by GIZ organization and Staatsministerium BadenWürttemberg. The field was provided by the College of Agriculture, UoD. The compost was provided by the Communal Waste Sorting Facility in Quashie, Semel District/ Directorate of Duhok Municipalities. The assistance of Dr. Fathi Abdulkareem Omer, Mr. Halgurd Rasheed Ismael, Mr. Masoud Hussein Mussa, Anas S. Mohamed and Mohammed Abdi in the field is highly acknowledged. Thank goes to Dr. Moyassar Mohammed Aziz for his assistance in data analysis. Thanks to Mr. Stefan Essel the project manager of GIZ Solid Waste Management Project. The paper was reviewed by Dr. Rafail S. Toma. The consultation advices of Dr. Michael Ernst are highly appreciated.

\section{REFERENCES}

- Abdel C.G. \& Ibrahim A.A. (2018). Risk evaluation of accumulated heavy metals in Radish (Raphanus sativus L. var. sativus) cultivars irrigated by varying water resources. Journal of Kerbala for Agricultural Sciences 5, 67-88.

- Brower, J. E., et al. (1998). "Field and laboratory methods for general ecology."

- Belitz, H.D., Grosch, W. and Schieberle, P., (2008). Kapitel 4:" Kohlenhydrate. Lehrbuch der Lebensmittelchemie, 6 .

- Brower J.E., Zar J.H. \& von Ende C. (1998). Field and laboratory methods for general ecology.
- Çalışkan Y., Barışçı S., Bektaş N. \& Tekbaş M. (2014). Composting of Municipal Solid Waste as a Useful Product.

- Commission E. (2006). Commission Regulation (EC) No 1881/2006 of 19 December 2006 setting maximum levels for certain contaminants in foodstuffs. Off J Eur Union 364, 5-24.

- Commission E. (2015). Commission Regulation (EU) $2015 / 1005$ of 25 June 2015 amending Regulation (EC) No 1881/2006 as regards maximum levels of lead in certain foodstuffs. Off. J. Eur. Union 161, 9-13.

- Commission E.E. (2008). Commission regulation (ec) no 149/2008 of 29 january 2008 amending regulation (ec) no 396/2005 of the european parliament and of the council by establishing annexes ii, iii and iv setting maximum residue levels for products covered by annex i thereto. Off J 58, 1-398.

- De Miguel E., Llamas J.F., Chacón E., Berg T., Larssen S., Røyset O. \& Vadset M. (1997). Origin and patterns of distribution of trace elements in street dust: unleaded petrol and urban lead. Atmospheric Environment 31, 2733 40.

- Eghball B., Ginting D. \& Gilley J.E. (2004). Residual effects of manure and compost applications on corn production and soil properties. Agronomy journal 96, 442-7.

- Emenky F.A., Khalaf A.S. \& Salim N.M. (2010). INFLUENCE OF TILLAGE AND WEED MANAGEMENT METHODS ON CHICKPEA (Cicer arietinum L.). I. YIELD AND YIELD COMPONENTS. Pakistan Journal of Weed Science Research 16. 
- Fergusson J.E. \& Kim N.D. (1991). Trace elements in street and house dusts: sources and speciation. Science of the Total Environment 100, 125-50.

- Frede W. (2006). Taschenbuch für Lebensmittelchemiker: LebensmittelBedarfsgegenstände-Kosmetika-Futtermittel. Springer-Verlag.

- Godbold D.L. \& Hüttermann A. (1988). Inhibition of photosynthesis and transpiration in relation to mercury-induced root damage in spruce seedlings. Physiologia Plantarum 74, 270-5.

- McLean J.E., Bledsoe B.E. \& Sourcebook E.E.A. (1992). Behavior of metals in soils. EPA Environmental Assessment Sourcebook, 19-56.

- Nageotte S.M. \& Day J.P. (1998). Lead concentrations and isotope ratios in street dust determined by electrothermal atomic absorption spectrometry and inductively coupled plasma mass spectrometry. Analyst 123, 59-62.

- No E.R. (2005). 396/2005 of the European Parliament and of the Council of 23 February 2005 on maximum residue levels of pesticides in or on food and feed of plant and animal origin and amending Council Directive 91/414/EEC. Off J L 70.

- Regulation A. (2014). No 1881/2006 as regards maximum levels of cadmium in foodstuffs. Norma Commission Regulation (EU) No 488.

- Sakalauskaite J., Kviklys D., Lanauskas J. \& Duchovskis P. (2006). Biomass production, dry weight partitioning and leaf area of apple rootstocks under drought stress. Sodininkyste Ir Darzininkyste 25, 283-91.

- Sezgin N., Ozcan H.K., Demir G., Nemlioglu S. \& Bayat C. (2004). Determination of heavy metal concentrations in street dusts in Istanbul E-5 highway. Environment international 29, 979-85.

- Shipley B. \& Vu T.T. (2002). Dry matter content as a measure of dry matter concentration in plants and their parts. New Phytologist 153, 359-64.

- Teramura A.H., Perry M.C., Lydon J., McIntosh M.S. \& Summers E.G. (1984). Effects of ultraviolet-B radiation on plants during mild water stress. III. Effects on photosynthetic recovery and growth in soybean. Physiologia Plantarum 60, 484-92.

- VDLUFA (2011a): Methode 2.1.3:

Mikrowellenbeheizter Druck-aufschluss, Handbuch der Landwirtschaftlichen Versuchsund Untersuchungsmethodik (VDLUFAMethodenbuch), Bd. VII Umweltanalytik, 4. Aufl., VDLUFA Verlag, Darmstadt.

- VDLUFA (2011b): Methode 2.2.2.5 "Bestimmung von ausgewählten Elementen in Pflanzen sowie in Grund- und Mischfuttermitteln mittels Massenspektrometrie mit induktiv gekoppeltem Plasma (ICP-MS)", 4. Aufl, VDLUFA Methodenbuch VII Umweltanalytik. 
يوخته

ل دويف ئهنجاميّن شروقه كرنا كوميوستى يتّ كو هاتيه بهرههم ئينان ل كارگهها كواشى يا كليّشى و تيّدا

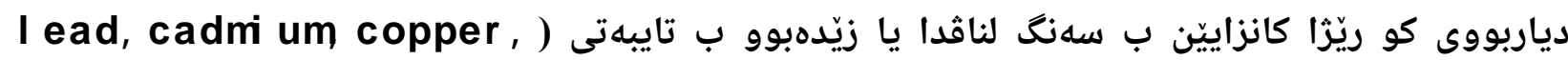
(ni ckel , chromi um cobal t and zi nc

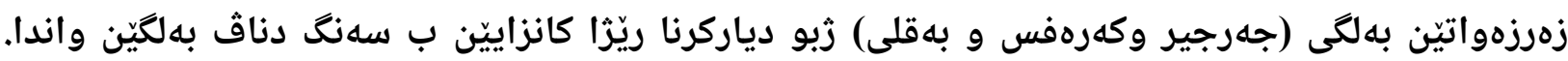

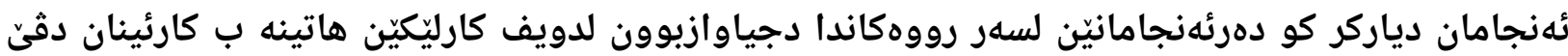

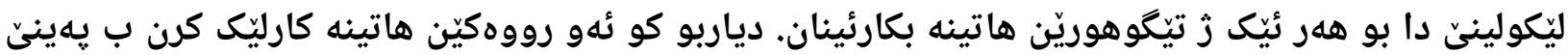

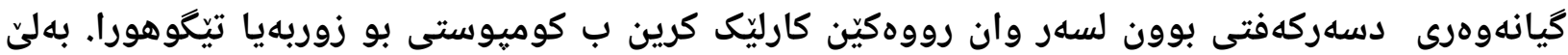

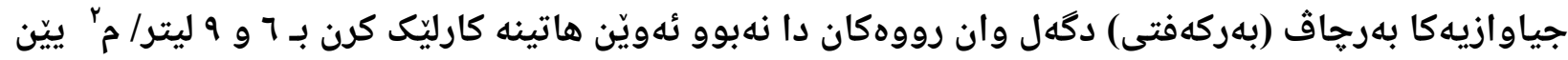
كوميوستى. ريّزا كانزاييّن ب سهنگ دناق هلمى نمووناندا لدويف ستاندارتيّن ياسايا خوارنى يا ئهورويى بوو

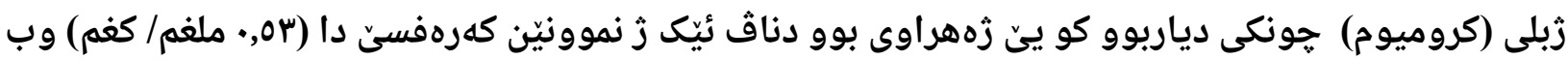

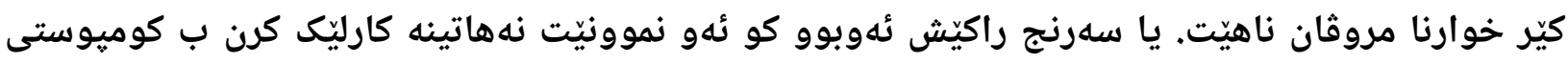

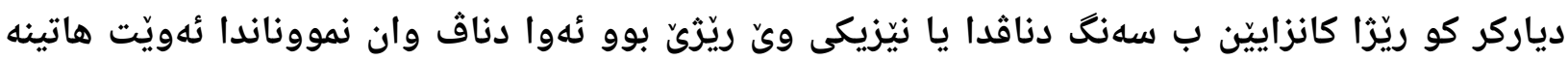

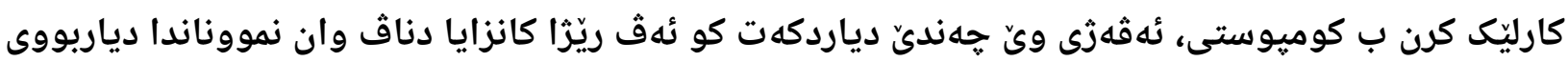

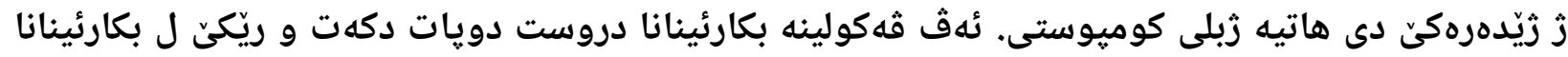

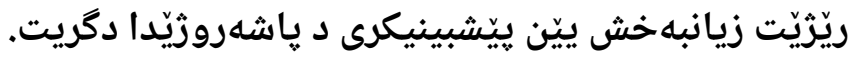

الخلاصة

اعتماداً على نتائج تحليل الكومبوست المنتج في معمل نفايات كواشي والذي اظهر زيادة في كميات العناصر الثقيلة (وخاصة الرصاص والكادميوم والنحاس والنيكل والكروم والكوبلت والزنك)، اجريت هيت هذي النه الدراسة على ثلاثة انواع من الخضراوات الورقية (الجرجير والكرفس والسلق) وذلك لتحديد كمية العناصر الثقيلة في اوراقها. اظهرت النتائج بأن استجابة النباتات قد اختلفت حسب المعاملاتلات المبات المستخدمة في الدراسة لكل من المتغيرات المدروسة. تبين ان النباتات المعاملة بالسماد الحيواني كانت متفوقة على الته تلك التي عوملت إنت

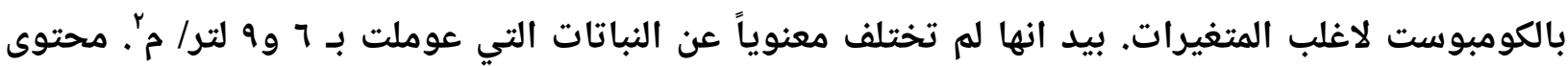
العناصر الثقيلة في جميع العينات كانت متوافقة مع قانون الغذاء الاوروبي ماعدا الكروم حيث ظهر بإنانه سام

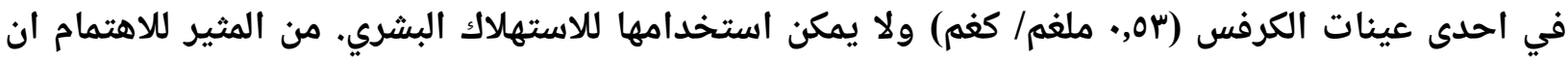
العينات التي لم تعامل بالكومبوست اظهرت نسب قريبة من التي عوملت بالكومبوست من حيث احتوائها على العناصر الثقيلة مما يدل على انها قد تلوثت من مصدر اخر غير الكومبوست. هذه الدراسة تؤكد على الاستخدام الصحيح للكومبوست وتمنع استخدام الكميات الضارة المحتملة في المستقبل. 